\title{
PENATALAKSANAAN PEMERIKSAAN CT-SCAN ORBITA MENGGUNAKAN BAHAN KONTRAS DENGAN KLINIS CA SEBASEA
}

\author{
Irma Rahmania \\ ATRO Patriot Bangsa Lampung \\ Corresponding author: Irma Rahmania \\ Email: rahmania2009@gmail.com
}

\begin{abstract}
Background: Orbita CT allows visualization of abnormalities that are not easily seen with konvensional radiography. As a comparison, tomogram are reconstructed by a computer and rotated as anatomical pieces on a monitor. Carcinoma transmits sebaceous is a tumor originating from a malignant sebaceous tumor. This carcinoma usually comes from meibom circles.Research Objectives: To find out the procedure of OrbitaCT-Scan examination using contrast material with clinical Ca Sebaceain Radiology Installation Dr. H. Abdul Moeloek Lampung Province

Methods: This study is descriptive qualitative with an observational approach

Results: After observation of the obtained results that the examination of CT-Scan Orbita using contrast material is done with special preparations, using pre-contrast and post-contrast axial slice which were then reconstructed into coronal and sagittal slice according to doctor and clinical needs.

Conclusions: The results of the picture show suggestive soft tissue tumor maligna in the lateral aspect of the palpebrae sinistra size of $1.9 \mathrm{~cm} \times 3.3 \mathrm{~cm} \times 2.2 \mathrm{~cm}$ which appears attached to the lateral aspect of the bulb oculis sinistra.
\end{abstract}

Keyword : CT-Scan orbita, Ca Sebasea

\section{Pendahuluan}

CT-Scan (Computed Tomography Scanner) adalah suatu prosedur yang digunakan untuk mendapatkan gambaran dari berbagai sudut kecil dari tulang tengkorak dan otak. Pemeriksaan ini berguna untuk melihat adanya gambaran lesi dan bentuk serta ukuran dari tumor, hematoma dan abses. (D.Soebagdjo, H. 2019).

CT-Orbita memungkinkan visualisasi kelainan yang tidak mudah terlihat dengan radiograf standar. Sebagai serangkaian tomogram yang direkontruksi oleh computer dan ditampilkan sebagai potongan anatomi pada monitor, CT-Scan Orbita mencari lesi desak ruang dengan lebih dini dan lebih tepat dibandingkan dengan teknik radiografi lain dan memberikan citra tiga dimensi struktur-struktur Orbita, terutama otot-otot ocular dan saraf optikus. (Kowalak, J.P. 2010).
Karsinoma kelenjar sebasea atau sering disebut Sebaceous gland car-cinoma (SGC) adalah tumor yang berasal dari kelenjar sebasea yang bersifat ganas. Karsinoma tersebut biasanya berasal dari kelenjar meibom yang terletak pada tarsal plate, namun dapat juga berasal dari kelenjar zeis dekat bulu mata atau kelenjar sebasea pada karunkula, alis, ataupun kulit wajah.

Kanker yang sering menyerang pada pria yaitu kanker paru, kolorektal, prostat, hati dan nasofaring. Jenis kanker yang sering dialami wanita adalah kanker payudara, leher rahim, kolorektal, ovarium dan paru. Sedangkan kanker yang sering dialami anak anak adalah kanker bola mata (Retinoblastoma) dan kanker darah (Leukemia) (Dinkes lampung, 2016).

Menurut data WHO, pada tahun 2012 terdapat 14,1 juta kasus baru di dunia dengan 8,2 juta penderita kanker yang meninggal dan 32,6 juta orang yang hidup dengan diagnosis 
kanker selama lima tahun. Berdasarkan data tersebut, terdapat $57 \%$ kasus baru, $65 \%$ kematian akibat kanker, dan $48 \%$ penderita kanker yang masih hidup dengan diagnosis kanker selama lima tahun. Kasus tersebut merupakan kasus di negara-negara berkembang, termasuk Indonesia (D.Soebagdjo, H. 2019).

Kejadian kanker atau tumor mata di Indonesia jarang terlaporkan secara spesifik dan terbatas pada regional-regional daerah di Indonesia. Menurut laporan Mansur (2017), Di RSUP. Dr. Wahidin Sudirohusodo, Makassar dari tahun 2014-2016 didapatkan 70 kasus tumor mata dengan jumlah perempuan $(67,2 \%)$ lebih banyak dari pada laki-laki $(32,8 \%)$. Berdasarkan umur, balita (0-5 tahun) lebih banyak dengan kasus retinoblastoma (50\%). Jenis tumor mata yang didapatkan adalah tumor intraokular (58,6\%), tumor ekstraokular (40\%), dan retrobulbar $(1,4 \%)$ (D.Soebagdjo, $\mathrm{H}$. 2019).

Berdasarkan hasil pre survey di RSUD Dr. H. Abdul Moeloek Provinsi Lampung pemeriksaan CT-Scan Orbita hanya ada 20 pasien dari 1.121 pasien selama bulan JuliOktober 2019. Penulis tertarik pada pemeriksaan CT-Scan Orbita dengan klinis karsinoma sebasea pada laki-laki, karena presentase tumor mata pada laki-laki lebih sedikit di-bandingkan perempuan, oleh karena itu pemeriksaan ini dilakukan dengan cermat dan dengan harapan dapat memberikan informasi tentang adanya pengaruh paparan sinar matahari pada perbedaan jenis kelamin terhadap karsinoma palpebral (ca sebasea).

\section{Metode}

Penelitian ini menggunakan penelitian deskriptif kualitatif dengan pendekatan observatif yang bertujuan untuk mengetahui prosedur penatalaksanaan pemeriksaan $C T$ Scan Orbita menggunakan bahan kontras dengan klinis ca sebasea

\section{Hasil dan Pembahasan}

Hasil Gambaran CT-Scan Orbita

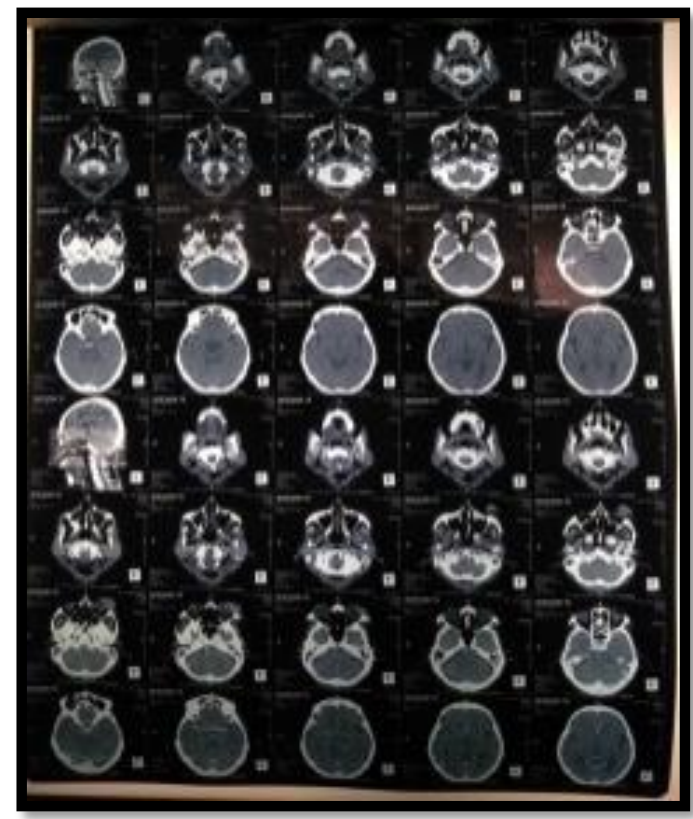

Gambar 1. CT-Scan Orbita Axial pre dan post kontras

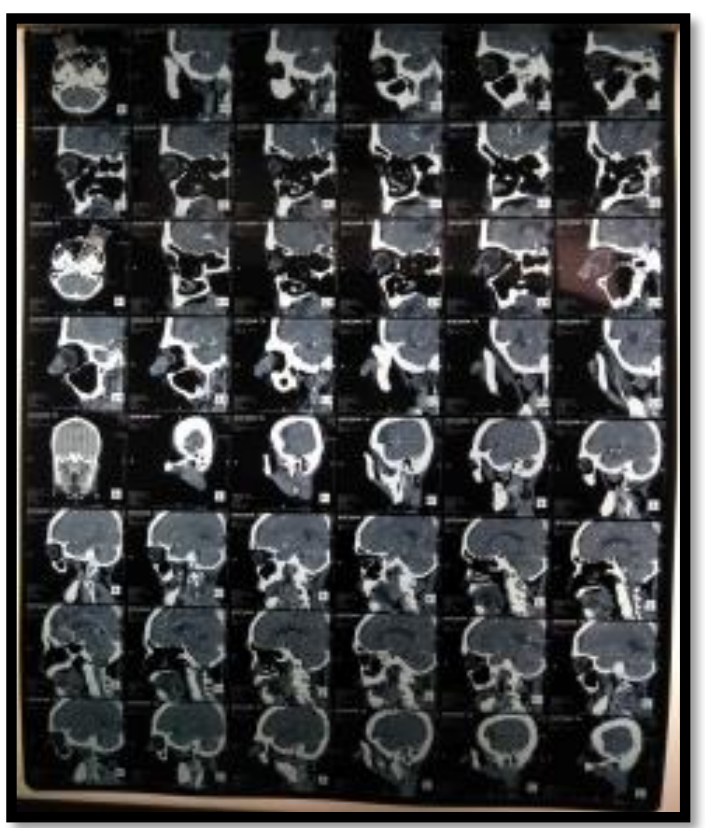

Gambar 2. CT-Scan Orbita sagital Post Kontras

Pemeriksaan CT-Scan Orbita menggunakan bahan kontras membutuhkan persiapan pasien secara khusus berupa hasil pemeriksaan laboratorium yaitu dengan hasil ureum 39 $(\mathrm{mg} / \mathrm{dl})$ dan creatnine $1,24 \quad(\mathrm{mg} / \mathrm{dl})$ yang bertujuan untuk mengetahui fungsi ginjal karena pemeriksaan ini memasukkan bahan kontras yang akan mempengaruhi kerja ginjal. Maka diharuskan pasien memiliki nilai laboratorium dalam batas normal apabila hasil laboratorium tidak normal dan bahan kontras disuntikkan maka itu akan memperburuk kerja 
ginjal, zat kontras yang terlanjur masuk kedalam tubuh akan meracuni tubuh (Contras Induct Nephropathy).

Selain persiapan pasien pada saat melakukan pemeriksaan komunikasi pada pasien sangat penting untuk dilakukan demi kelancaran jalannya pemeriksaan, pasien diminta untuk melepaskan perhiasan dan benda-benda logam di sekitar objek pemeriksaan, serta pasien diberikan instruksi untuk tenang dan tidak bergerak selama pemeriksaan berlangsung sehingga hasil gambaran yang diperoleh baik, radiasi yang ditimbulkan pada pemeriksaan $C T$ Scan besar sehingga tidak dianjurkan untuk melakukan pengulangan pemeriksaan. Pada saat pengisian data pasien, studi pemeriksaan, dan pasien position harus dilakukan dengan benar serta teliti. Secara teoritis tidak ada perbedaan, namun saat di lapangan dalam pemeriksaan ini ketika perawat melakukan skin test media kontras tidak didampingi oleh dokter.

Pada pemeriksaan CT-Scan Orbita dengan media kontras pada kasus ca sebasea menggunakan scan time 30 detik dan slice thickness $1,25 \mathrm{~mm}$, semakin kecil potongan slice thickness maka potongan gambar yang dihasilkan semakin banyak sehingga kelainan yang kecil dapat terlihat.

Pasien diposisikan di atas meja pemeriksaan dengan batas atas dua jari dari vertex. Kepala diposisikan dimana garis tengah kepala disejajarkan dengan garis tengah head holder dan garis tinggi kepala setinggi MAE. Lalu masukkan data pasien, study pemeriksaan dan pasien position pada program computer. Kemudian ambil terlebih dahulu gambaran scannogram, lalu setting irisan dengan batas atas vertex dan batas bawah simpisis mentis tercakup. Kemudian lakukan pengambilan scanning tanpa kontras media dengan potongan axial 24 slice.

Setelah dilakukan pengambilan gambaran pre kontras maka dilanjutkan dengan pengambilan gambaran scanning post kontras media dengan cara dilakukan pemasukkan media kontras $50 \mathrm{cc}$ dan aquades $20 \mathrm{cc}$ menggunakan injector dengan delay 40 detik. Kemudian lakukan pengambilan scanning setelah injeksi kontras media.

Pemeriksaan CT-Scan orbita menggunakan bahan kontras dengan klinis ca sebasea dari hasil wawancara dengan dr.radiolog bahwasannya menggunakan semua potongan (axial, coronal, dan sagital), sedangkan pada penatalaksanaannya cukup menggunakan potongan axial dan sagital karena sudah menghasilkan diagnose pada hasil gambaran. Sesuai dengan kebutuhan dokter dan klinis. Setelah scanning selesai lakukan proses pengolahan gambar, hasil gambaran potongan axial post kontras akan direkontruksi menjadi potongan sagital. Pasien dapat dikeluarkan dari ruangan.

Dari hasil expertise dokter terhadap pemeriksaan CT-Scan Orbita menggunakan bahan kontras dengan klinis ca sebasea yaitu tampak lesi atau kelainan yang tampak kepadatannya lebih dari jaringan sekitar disisi pinggir kelopak mata kiri dengan ukuran $1,9 \mathrm{~cm}$ x 3,3 cm x 2,2 cm, lesi tampak menempel pada bola mata kiri di sisi pinggir. Sisi kedua bola mata, nervus optikus bilateral, canales nervi optici bilateral tampak simetris dan tidak tampak kelainan atau lesi. Bagian belakang mata, system tulang, bagian dalam kepala tergambarkan dalam batas normal, tidak tampak lesi. Setelah pemasukan media kontras tidak tampak penyengatan patologis. Dari hasil gambaran axial dan sagital terlihat jelas klinis ca sebasea pada potongan sagital orbita sinistra pada slice ke 6 (enam).

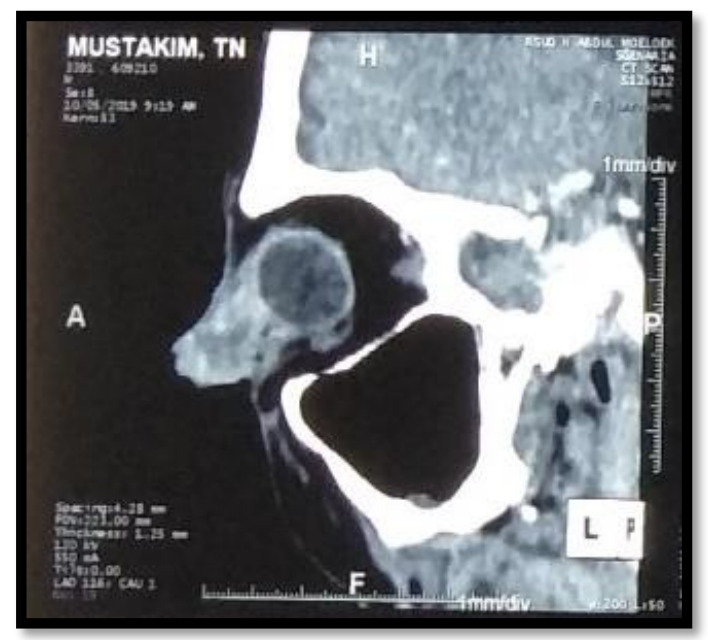

Gambar 3. CT-Scan sagittal Orbita Sinistra Post Kontras

Jadi dari hasil tersebut, klinis atau dugaan sebelumnya yang didapat dari hasil expertise dokter adalah benar bahwa mengindikasian $\mathrm{ca}$ sebasea dan terdiagnosa jaringan berupa tumor ganas disisi pinggir kelopak mata kiri yang tampak menempel pada bulbus oculis sinistra aspek lateral. 


\section{Simpulan}

Pada pemeriksaan CT-Scan Orbita menggunakan bahan kontras membutuhkan persiapan pasien yaitu, pemeriksaan ureum dan creatine, puasa 6 jam sebelum pemeriksaan mengisi inform consent. Alat dan bahan yang digunakan, pesawat CT-Scan multi slice, spuit injeksi $1 \mathrm{cc}$, kontras media $50 \mathrm{cc}$, aquades 20 $\mathrm{cc}$, injector, venlfon no.20, kapas alkohol, water soluble, plaster, oksigen, obat anti alergi, dan hasil pemeriksaan laboratorium ureum creatinin. Teknik pemeriksaan CT-Scan Orbita menggunakan bahan kontras dengan klinis $c a$ sebasea yaitu dengan mengatur posisi pasien pada meja pemeriksaan, memasukkan data pasien, study pemeriksaan dan pasien position pada program komputer, proses scannogram, pengambilan scanning pre dan post kontras, slice thickness yang digunakan $1,25 \mathrm{~mm}$, menggunakan potongan axial pre kontras dan post kontras yang kemudian direkontruksi menjadi potongan coronal dan sagital sesuai dengan kebutuhan dokter dan klinis.

Hasil gambaran dari penatalaksanaan pemeriksaan CT-Scan Orbita menggunakan bahan kontras terdiagnosa sugestif soft tissue tumor maligna di aspek lateral palpebrae sinistra ukuran $1,9 \mathrm{~cm} \times 3,3 \mathrm{~cm}$ x 2,2 cm yang tampak menempel pada bulbus oculis sinistra aspek lateral.

\section{Daftar Pustaka}

Ballinger, W.Philip, 2003 Radiographic Potitions and Radiologic Procedures, Volume Three, Tenth Edition, The Mosby Elseiver, St. Louis.

BAPETEN, 2013. Peraturan Kepala Badan Pengawas Tenaga Nuklir Nomor 4 Tahun 2013 Tentang Proteksi Radiasi Dan Keselamatan Radiasi Dalam Pemanfaatan Tenaga Nuklir, BAPETEN, Jakarta

D. Soebagjo, Hendrian, 2019. Onkologi Mata, Airlangga University Press, Surabaya.

Einsberg, L.Ronald and Johnson, M.Nancy, 2012. Comprehensive Radiographic Pathologi, Jeanne Olson, USA.

Fathur, San K, 2018. Metodologi Penelitian Farmasi Komunikasi Dan Eksperimental, CV Budi Utama, Yogyakarta.

Ilyas, Sidarta, 2001. Ikhtisar Ilmu Penyakit Mata, FKUI,Jakarta.

Pearce, C.Evelyn, 2013. Anatomi Dan Fisiologi Untuk Paramedis, Gramedia Pustaka Utama, Jakarta.
Rasad, Sjahriar, 2017. Radiologi Diagnostik, FKUI, Jakarta.

Romans, E.Lois., 2011. Computed Tomography for Technologis, C\&C Offset, China.

Syaifuddin, 2011. Anatomi Fisiologi Untuk Mahasiswa, EGC, Jakarta.

Wijokongko, Sigit, 2016. Protokol Radiologi CTScan dan MRI, Inti Medika Pustaka, Magelang 